\title{
Comparative Examination of Commonly Used Some Fixatives with Routine Histochemical Staining's for The Optimal Histological Appearance in The Gill Tissue of Zebrafish
}

\author{
Aykut ULUCAN', Hayati YÜKSEL², Muhammed Bahaeddin DÖRTBUDAK², Seda YAKUT³ \\ ${ }^{1}$ Bingol University, Vocational School of Health Services, Department of Medical Services and Techniques, Turkey \\ ${ }^{2}$ Bingol University, Faculty of Veterinary Medicine, Department of Pathology, Turkey \\ ${ }^{3}$ Bingol University, Faculty of Veterinary Medicine, Department of Histology and Embryology, Turkey
}

\begin{abstract}
Histopathological studies related to Zebrafish which are used as a model organism in researching the pathogenesis of many diseases increase day by day. Because of the increasing importance of zebrafish research, experiments on this animal model are more prominent and gill tissue is frequently examined in various disease models using zebrafish. As it is known, at the end of the experimental animal model studies, if the histopathological examination is to be done, the tissues should be fixed. The purpose of fixation is to keep cellular and extracellular components in vivo as much as possible. Therefore, the choice of fixation methods and fixatives has a significant effect on tissue processing. In this study, we aimed to optimize fixation techniques and staining protocols for producing ideal slides and histological images of gill tissue in zebrafish. In our study, to determine the optimal histology in the zebrafish-gill tissue, the tissues were fixed with Bouin's, Carnoy's, $10 \%$ neutral buffered formalin (NBF), Davidson's, and Dietrich's solutions. Following the routine tissue processing, the sections were stained with Hematoxylin and Eosin (H\&E) and Masson's Trichrome (MT) stains. Consequently, tissue morphology was best preserved with Bouin's and NBF solutions. The best results in H\&E stain were obtained from tissues fixed with NBF solution, while Dietrich's solution fixation was found to be ideal for MT staining.
\end{abstract}

Keywords: Fixatives, Hematoxylin and Eosin, Masson's Trichrome, Zebrafish, Gill

\section{Zebra Balığ1 Solungaç Dokusunda Optimal Histolojik Görünüm için Rutin Histokimyasal Boyama ile} Sık Kullanılan Fiksatiflerin Karşılaştırmalı Olarak İncelenmesi

\section{ÖZ}

Birçok hastalığın patogenezinin araştırılmasında model bir organizma olarak kullanılan Zebra balı̆̆ı ile ilgili histopatolojik çalışmalar gün geçtikçe artmaktadır. Zebra balığı araştırmalarının artan önemi nedeniyle, bu hayvan modelindeki deneyler daha önemlidir ve solungaç dokusu zebra balığı kullanılan çeşitli hastalık modellerinde sıklıkla incelenir. Bilindiği üzere, deneysel hayvan modeli çalışmalarının sonunda, eğer histopatolojik inceleme yapılacaksa, dokular fikse edilmelidir. Fiksasyonun amacı, hücresel ve hücre dışı bileșenleri mümkün olduğunca in vivo halde korumaktır. Bu nedenle, fiksasyon yöntemlerinin ve fiksatiflerin seçiminin doku takibi üzerinde önemli bir etkisi vardır. Bu çalışmada, zebra balığ1 solungaç dokusundan ideal preparatlar ve histolojik görüntüler elde etmek için fiksasyon tekniklerini ve boyama protokollerini optimize etmek amaçlanmıştır. Çalışmamızda, zebra balığı-solungaç dokusundaki ideal histolojiyi belirlemek için, dokular, Bouin, Carnoy, \%10’luk nötral tamponlu formaldehit, Davidson ve Dietrich solüsyonları ile fikse edilmiştir. Rutin doku işleminin ardından, kesitler Hematoksilen ve Eosin (H\&E) ve Masson Trikrom (MT) boyaları ile boyandı. Sonuç olarak, doku morfolojisi en iyi Bouin ve NBF solüsyonları ile korunmuştur. H\&E boyamasında en iyi sonuçlar NBF çözeltisi ile fikse edilmiş dokulardan elde edilirken, Dietrich solüsyonu fiksasyonunun MT boyaması için ideal olduğu bulundu.

Anahtar Kelimeler: Fiksatifler, Hematoxylin ve Eosin, Masson Trikrom, Zebra balığı, Solungaç

To cite this article: Ulucan A. Yükesel H. Dörtbudak M.B. Yakut S. Comparative Examination of Commonly Used Some Fixatives with Routine Histochemical Staining's for The Optimal Histological Appearance in The Gill Tissue of Zebrafish. Kocatepe Vet J. (2019) 12(2):158167.

Submission: 13.02.2019 Accepted: 26.04.2019 Published Online: 15.05.2019

ORCID ID; AU: 0000-0001-8844-8237, HY: 0000-0002-1724-1770, MBD: 0000-0001-5777-964X,

SY: 0000-0003-1673-5661

*Corresponding author e-mail: aulucan@bingol.edu.tr 


\section{INTRODUCTION}

The importance of histological and pathological examinations is unquestionable when evaluating the results of screening studies with fish models (disease research, environmental pollutants, toxicologicalcarcinogenic-teratogenic research, etc.) (Pikarsky et al. 2004, Flores-Lopes and Thomaz 2011, Strzyzewska et al. 2016, Hadi and Alwan 2012, Huiting et al. 2015). In today's scientific studies, zebrafish is an important model organism in terms of having some advantages. These advantages are similar genomic structures, metabolic activities, embryonic developmental characteristics, immune systems, and histological structures in some tissues (Mohseny and Hogendoorn 2014, Morris 2009). In addition, features such as easy breeding, feeding, short generation, durability, and high fecundity have increased the importance of zebrafish in experimental researches (Muto and Kawakami 2013, Newman et al. 2014).

Gill tissue is examined in most of the toxic and infectious disease models made with zebrafish (Brundo and Salvaggio 2018, Souza et al. 2017, Progatzky et al. 2016, Chandrarathna et al. 2018, Christoffersen et al. 2017). Most of the teleosts use the gills as the main respiratory surface. Teleosts have four pairs of gill arches extending from the floor to the roof of the buccal cavity. Each gill arch contains a plurality of gill filaments, each consisting of two halves called hemibranchs. Each hemibranch has many thin subdivisions called gill lamellae. The purpose of these structures is to provide a large surface area that supports respiratory and excretory functions. Gill filaments have central cartilaginous support, afferent and efferent arterioles, and other anastomosing vessels comprising the central venous sinus. They are covered with a thin epithelium continuation of the covering the gill arches and the oral mucosa of the buccal cavity. Each lamella is best regarded as a thin cell envelope. The spaces between the pillar cells called lacunae connect afferent and efferent arterioles. The contractile pillar cells control the lacunar diameter, thereby regulating blood flow (Genten et al. 2010, Roberts 2012).

The aim of fixation is to keep cellular and extracellular components as close as possible to the tissue structure in vivo. In the fixation process with many fixatives, the existing microorganisms in the tissues die, autolysis stops and the macromolecular structure of the tissue is balanced by forming crosslinks between the tissue components. Fixation without specimen distortion is difficult because all fixation methods produce artifacts such as shrinkage, swelling, hardening, and color change. Moreover, fixation and fixative selection may be of great importance in the tissue processing stages, mainly in cross-sectional sampling and staining procedures (Bancroft and Gamble 2019).

In this study is intended to be a resource for scientists interested in human and model organism histology, quality, consistency, sectioning, staining, and histological visualization. We aim to optimize fixation techniques and staining protocols to produce ideal slides and images to explain common difficulties associated with various aspects of zebrafish histology. In our study, the effect of fixation with Bouin's, Carnoy's, 10\% neutral buffered formaldehyde (NBF), Davidson's and Dietrich's solutions on the zebrafish gill tissue histology as a result of hematoxylin and eosin ( $\mathrm{H} \& \mathrm{E}$ ) and Masson's Trichrome (MT) staining were examined. Also, we tried to develop the fixation methods with compared of Bouin's, Carnoy's, NBF, Davidson's and Dietrich's solutions and, adapted staining procedures with $\mathrm{H} \& \mathrm{E}$ and MT stains for gill tissue of fish.

Bouin's solution is suitable for a variety of tissue types and is frequently recommended for small biopsy samples. It is known that Bouin's solution lyses erythrocytes in part or completely. It has been reported that it causes swelling in collagen with the dissolution of iron and calcium stores, but it protects the glycogen and connective tissue well. It creates bright staining with cytoplasmic dyes and protects the nucleus extremely well with chromosomes. Since the basophilic character of the cytoplasm is neutralized with the picric acid in the content of Bouin's solution, it allows clear staining of the nucleus and cytoplasm (Carson and Hladik 1996, Culling 1983, Singhal et al. 2016, Roberts 2012, Bancroft and Gamble 2019).

Carnoy's solution is used in cases where fast and effective fixation is required and suitable for the fixation of all types of tissue. It is good advice for glycogen and plasma cells. Since it is a good nuclear fixative, it is also used in cases where nucleic acids need to be examined. It is also preferred for histochemical and specific staining of fibrous proteins and carbohydrate complexes. After fixation, the lysis of erythrocytes and soluble cell granules in acid can cause loss of pigments in tissues. It has been reported that it cannot protect the collagen tissue and does not stain the acid-fast bacilli well. The Carnoy's solution is expensive and also has the disadvantage of fixative, such as shrinkage in tissues (Ahmed et al. 2011, Pereira et al. 2015, Roberts 2012).

NBF is a buffered form of $10 \%$ formalin solution to $\mathrm{pH} 7.0 \pm 0.2$ with various phosphate salts. This buffering process eliminates the various disadvantages of formaldehyde, such as the lysis of erythrocytes and the formation of formalin pigment (especially blood vessels and bloody tissues), and provides longer-term use. In NBF fixation, aldehyde bonds are formed between proteins and therefore the in vivo relationships of tissue components remain 
constant. Various tissue samples (surgical samples and biopsies) are routinely fixed in formaldehyde (Gnanapragasam 2010). Formalin fixation paralyzes cell metabolism and preserves tissue structures for accurate histopathological diagnosis (Nechifor-Boilă et al. 2015). Formaldehyde in the NBF form is the most commonly used fixative because it preserves a large range of tissues and tissue components and is also quite inexpensive (Maraschin et al. 2017). This fixative is useful in many special dyes and even immunohistochemical applications (Ahmed et al. 2011, Spaniol et al., 2016, Stefanović et al. 2017, Roberts 2012).

Davidson's solution is a good choice for the fixation of various tissues, such as bone marrow samples, gynecological materials, breast tissue, tumors, especially eyes and testicular tissues, lymph nodes, and biopsy materials. It provides fast and effective penetration to the tissues, so the morphological details are well preserved. One of the most important advantages of fixative is that does not cause shrinkage in tissues and minimal formalin pigmentation. This fixative can quickly penetrate into tissues and is easily removed from the tissues, so there is no need to rinse after long-term fixation. But, it may also lead to lysis of erythrocytes. Immunohistochemical staining results were also successful in fixation with this solution (Eltoum et al. 2001, Howard et al. 2004, Latendresse et al. 2002, Sahota et al. 2013, Telser, 2006).

Dietrich's solution is used in most experimental research, using many aquatic animals, zebrafish and small animal samples such as copepods (zooplankton), and one of the aquatic vertebrates like amphipods. The fixative has a synergistic interaction with the decalcification process. It breaks down electrostatic and hydrogen bonds and may lead to denaturation and degradation of nucleic acids with proteins in tissue samples. It is more effective in the fixation of nucleoproteins than cytoplasmic proteins (Dietrich and Krieger 2009, Feist et al. 2004, Berzins et al. 2011, Peterson et al. 2013, Khan and Thulin 1991, Uslu et al. 2017).

It has been reported that histochemical dyes such as H\&E, MT, Periodic Acid Schiff (PAS), Paraldehyde Fuchsin (PAF), Toluidine blue, Alcian blue, Alizarin red, Oil red, Bodian Protargol and Von Kossa stains have been used in studies performed in zebrafish (Bensimon-Brito et al. 2012, Çakıc1 and Üçüncü 2007, Nusslein-Volhard and Dahm 2002, Ung et al. 2010). In our study, H\&E and MT stains, the most common histological staining methods used in routine histopathology, were preferred. Hematoxylin stains nucleic acids in the nucleus and Eosin stains cytoplasm and extracellular proteinous structures. H\&E provides light microscopic observation of tissues and intercellular structures; therefore, in a well-made tissue, intranuclear details can be distinguished. H\&E staining is also used to provide adequate general information about cells and tissues and to diagnose major histopathological changes. It has advantages such as easy application, reliable and low cost (Kumar and Kiernan 2010, Bancroft and Gamble 2019).

Compared to H\&E staining, it is preferred for a more specific diagnosis by demonstrating increased connective tissue and collagen fibers with MT staining. It allows the cells to be distinguished from collagen fibers around them. Through Wiegert's ferrous hematoxylin in MT, various granules and fibrillar structures, myelin sheath, muscle epithelium, and even spirochetes and cytoplasmic details are more clearly displayed. In MT staining, ponceau and acid fuchsin, together with aniline blue or methyl green, help to stain the connective tissue prominently in bluish or light green. With MT staining, the diagnosis of disorders such as collagen growth, tumors (especially muscle tissue and fibroblast origin), hematopathological, neuromuscular, and dermatological disorders and liver cirrhosis and kidney (pyelonephritis) diseases can be diagnosed. Bouin's, Zenker's, Helly, Formal sublimate, Formalinzinc, and Picro-mercuric alcohol fixatives have been reported to be the other ideal fixatives for this staining method (Martinello et al. 2015, Carson and Hladik 1996, Mao et al. 2016, Cima et al. 2017, Rahunen et al. 2016).

\section{MATERIALS and METHODS}

In this study, 30 zebrafish (Danio rerio, wild type, 1year-old) were divided into five groups with 6 fish in each group $(n=6)$. The study materials were taken from our earlier work (The specified study was carried out at Bingol University Animal Research Center with the permission of Bingol University Animal Experiments Local Ethics Committee dated 26.09.2014 and numbered 2014.09.02 and this study was partially supported by The Scientific and Technological Research Council of Turkey (TUBITAK) with $215 Z 467$ numbered project.

Zebrafish care and maintenance: Established protocols for zebrafish care and feeding were applied (Westerfield 2000).

Preparation and application of fixatives: Fixatives used in the study (Bouin's, NBF, Carnoy's, Davidson's and Dietrich's fixatives), fixation times and post-fixation applications are given in Table 1. In addition, the chemicals and their amounts used in the preparation of fixatives are shown in the table state for each fixative (Table 2). Fixation was performed at room temperature $\left(21^{\circ} \mathrm{C}\right)$ for all samples. After fixation, decalcification was performed for 5 days according to Versanate EDTA method (Mueller et al. 
2017) and then tissue samples were taken for routine histopathological examination (Bancroft and Gamble 2019). We do not prefer to acidic decalcification because this destroys DNA and causes pale H\&E staining.

Anesthesia, necropsy and histopathological examination: Euthanasia was performed by adding with $160 \mathrm{mg} / \mathrm{L}$ Tricaine-S pH 7.0 (tricaine methanesulfonate, Syndel, USA) in system water. It should be noted that the relative merits of Tricaine-S and/or hypothermal shock through immersion in ice water $\left(2-4^{\circ} \mathrm{C}\right)$ have been recently debated (Matthews and Varga 2012, Wilson et al. 2009). To ensure fast euthanasia in fish, both methods (cold, Tricaine) were combined, allowing the fish do not react to the following immersion in fixatives steps. After the routine tissue processing, 5 micron thick sections were taken from the paraffin blocks with rotary microtome. The used fixative may influence staining method. For this reason, we have optimized staining procedures for both the fixative the tissues we are stained. In the present study, we preferred the H\&E staining protocol, in which the study by Cooper et al. 2018 achieved optimal results for zebrafish (Copper et al. 2018). The samples were stained with MT according to previous studies (Carson and Hladik 1996, Alturkistani et al. 2016, Bancroft and Layton 2019) and MT kit (with aniline blue) was purchased commercially (Masson trichrome kit, Catalog number 04-010802; Bio-Optica, Italy).

Subsequently, the slides were evaluated under a light microscope and the results were scored. In the evaluation, general staining character of tissues with $\mathrm{H} \& \mathrm{E}$ and staining of collagen fibrils with MT were taken into consideration. According to this; the staining levels of tissues were classified as, no staining $(0)$, mild staining $(+1)$, moderate staining $(+2)$ and severe staining $(+3)$. In this evaluation, the scores of the group averages of samples prepared with different fixatives and stained with H\&E and MT were presented graphically (Figures 1,2).

\section{Findings}

Microscopic examination of gill tissues taken from fish in the experimental groups showed different staining densities in both $\mathrm{H} \& \mathrm{E}$ and MT staining. $\mathrm{H} \& \mathrm{E}$ and $\mathrm{MT}$ staining reaction scores of experimental groups obtained by histopathological examination of gill tissues are given in Figures 1 and 2.

Bouin's solution fixed tissue findings: In $H \& E$ staining, common lysis of erythrocytes, well preserved primary and secondary lamellar structure morphology and clearly differentiated pillar cells were observed.
Eosinophilic and basophilic cellular structures were found to be adequately stained in a differential manner. Although collagen fibers were seen to be swollen, MT staining revealed adequate staining (Figure 3A-3B).

Carnoy's solution fixed tissue findings: In $H \& E$ staining, it was observed that widespread lysis in erythrocytes, primary and secondary lamellar structure morphology were not well protected, the lamellar epithelium was swollen and irregular, and pillar cells could not be clearly identified. Eosinophilic and basophilic cellular structures were not stained in a sufficient differential and generally, excessive staining was formed. However, it was revealed that the collagen fiber morphology was well preserved and sufficient staining was achieved with MT stain (Figure 3C-D).

NBF fixed tissue findings: In H\&E staining, it was observed that the erythrocytes did not lysize and had normal histological morphology, the secondary and primary lamellar structure morphology was adequately protected, but there was a slight shrinkage in the lamellar epithelium and the pillar cells could be clearly selected. Eosinophilic and basophilic cellular structures were clearly stained in a differential manner and generally, there is ideal staining. The morphology of collagen fibers was well preserved and partially weakened by MT staining (Figure 3E-F).

Davidson's solution fixed tissue findings: In H\&E staining, the presence of lysis in the erythrocytes, limited preservation of the primary and secondary lamellar structure morphology, and significant swelling and irregularity in the lamellar epithelium were detected. However, the pillar cells could be clearly selected. Eosinophilic and basophilic cellular structures were clearly stained in a differential manner and generally, there is ideal staining. It was observed that the collagen fiber morphology was well preserved and sufficient staining was achieved with MT stain (Figure 3G-H).

Dietrich's solution fixed tissue findings: In $H \& E$ staining, the presence of partial lysis of erythrocytes, primary and secondary lamellar structure morphology was partly preserved, the lamellar epithelium was slightly swollen, and the pillar cells were clearly distinguishable. Eosinophilic and basophilic cellular structures were stained differentially and in general, weak staining was determined. The morphology of the collagen fibers is well preserved and optimal staining is achieved with MT stain (Figure 3I-J). 
Table 1. Fixatives, application times and post-fixation procedures.

\section{Fixatives}

\begin{tabular}{|c|c|c|c|c|c|c|}
\hline \multirow{2}{*}{\multicolumn{2}{|c|}{ Fixation $\&$ other application times }} & Bouin's & Carnoy's & NBF & Davidson's & Dietrich's \\
\hline & & $12 \mathrm{~h}$ & $2 \mathrm{~h}$ & $48 \mathrm{~h}$ & $24 \mathrm{~h}$ & $24 \mathrm{~h}$ \\
\hline \multirow{3}{*}{$\begin{array}{l}\text { Post-fixation } \\
\text { applications }\end{array}$} & $50 \%$ Ethanol & $\begin{array}{l}3 \text { changes } \\
\text { in } 12 \mathrm{~h}\end{array}$ & ----- & ----- & ----- & ----- \\
\hline & $70 \%$ Ethanol & $\begin{array}{l}3 \text { changes } \\
\text { in } 12 \mathrm{~h}\end{array}$ & ----- & ----- & ----- & ----- \\
\hline & $100 \%$ Ethanol & ----- & $12 \mathrm{~h}$ & ----- & ----- & ----- \\
\hline
\end{tabular}

Table 2. Fixatives and their contents.

\begin{tabular}{|c|c|c|c|c|c|}
\hline \multirow[t]{2}{*}{ Contents } & \multicolumn{5}{|c|}{ Fixatives } \\
\hline & Bouin's & Carnoy's & NBF & Davidson's & Dietrich's \\
\hline Formaldehyde & $250 \mathrm{ml}$ & ----- & $100 \mathrm{ml}$ & $250 \mathrm{ml}$ & $100 \mathrm{ml}$ \\
\hline Acetic acid & $750 \mathrm{ml}$ & $100 \mathrm{ml}$ & ----- & $125 \mathrm{ml}$ & $20 \mathrm{ml}$ \\
\hline Picric acid & $50 \mathrm{ml}$ & ----- & ----- & ----- & ----- \\
\hline Chloroform & ----- & $30 \mathrm{ml}$ & ----- & ----- & ----- \\
\hline Ethanol (95\%) & ----- & $600 \mathrm{ml}$ & ----- & $375 \mathrm{ml}$ & $300 \mathrm{ml}$ \\
\hline Distilled water & ----- & ----- & $900 \mathrm{ml}$ & $375 \mathrm{ml}$ & $580 \mathrm{ml}$ \\
\hline $\begin{array}{l}\text { Sodium dihydrogen phosphate, } \\
\text { monohydrate }\left(\mathrm{NaH}_{2} \mathrm{PO}_{4} * \mathrm{H}_{2} \mathrm{O}\right)\end{array}$ & ----- & ----- & $4 \mathrm{~g}$ & ----- & ----- \\
\hline $\begin{array}{l}\text { Disodium hydrogen phosphate, } \\
\text { anhydrous }\left(\mathrm{Na}_{2} \mathrm{HPO}_{4}\right)\end{array}$ & ----- & ----- & $6,5 \mathrm{~g}$ & ----- & ----- \\
\hline
\end{tabular}

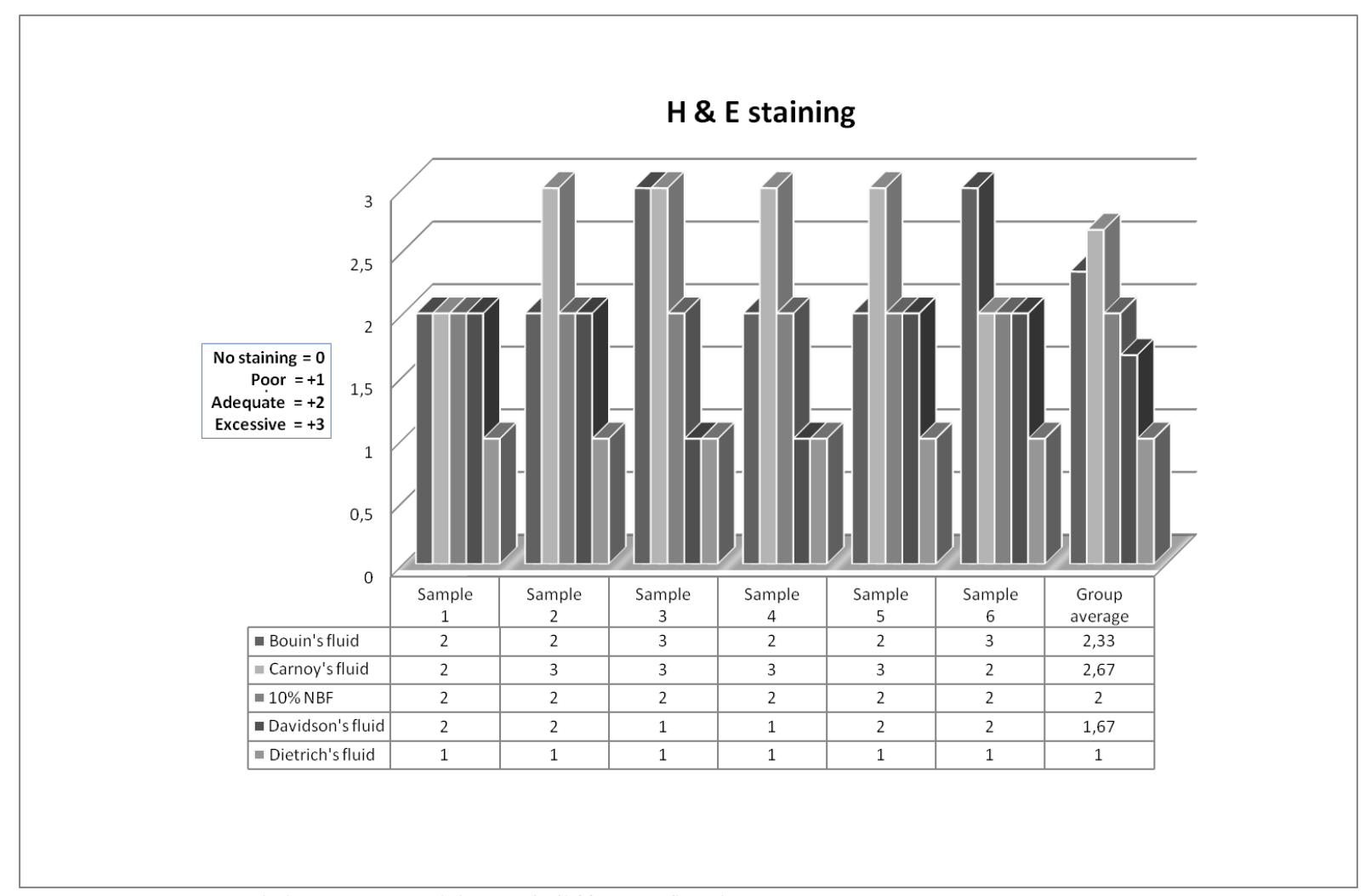

Figure 1. H\&E staining scores with used different fixatives. 


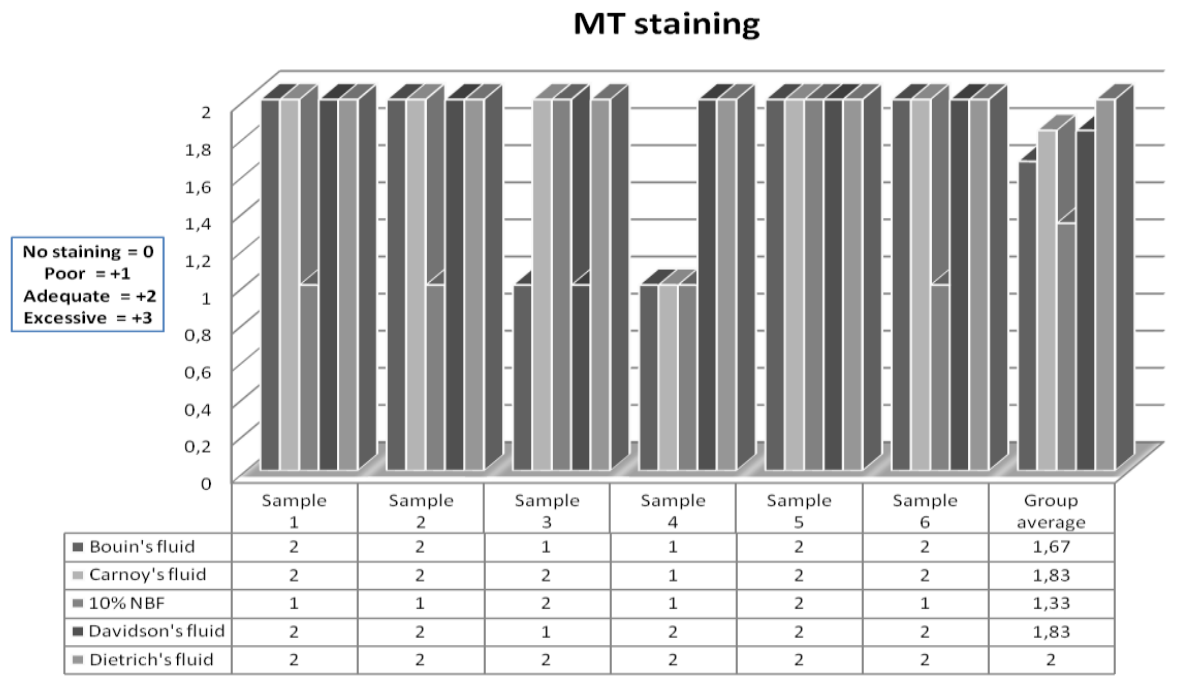

Figure 2. MT staining scores with used different fixatives.

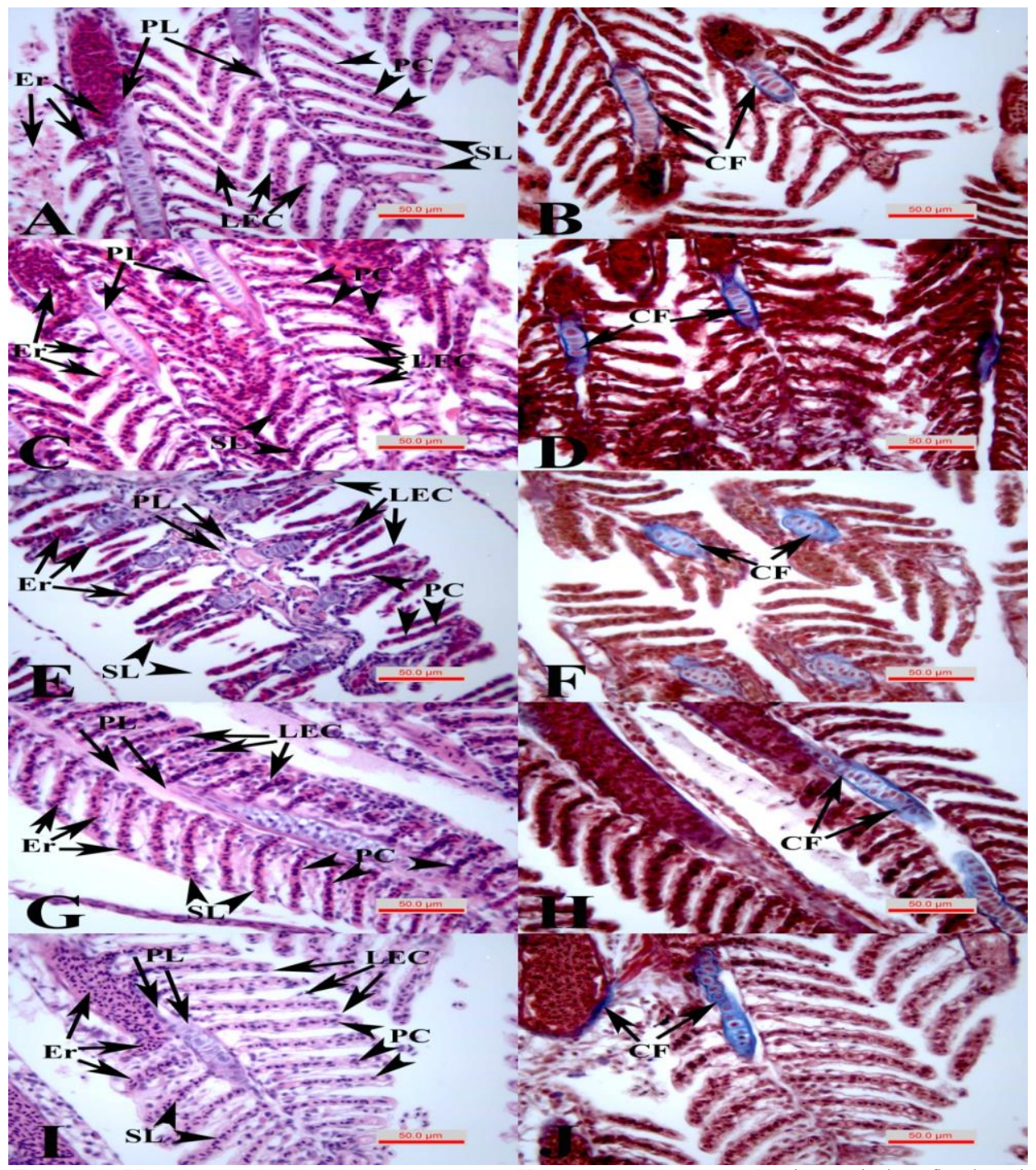

Figure 3. Histology of zebrafish gill tissues, X400 magnification. Bouin's solution fixed and H\&E (A) and MT (B) stained tissue sections. Carnoy's solution fixed and H\&E (C) and MT (D) stained tissue sections. NBF fixed and H\&E (E) and MT (F) stained tissue sections. Davidson's solution fixed and H\&E (G) and MT (H) stained tissue sections. Dietrich's solution fixed and H\&E (I) and MT (J) stained tissue sections. Er: Er: erythrocytes, PL: primary gill lamellae, SL: secondary gill lamellae, LEC: Lamellar epithelial cells, PC: Pillar cells, CF: Collagen fibers. 


\section{DISCUSSION}

Tissue and cellular structures can be examined anywhere on the entire slide. Ideally, any methods used to achieve this would minimize the occurrence of an artifact. Any artifact that may be formed in the tissues, by accidental or during tissue processing will lead to deviations in the histological appearance and inaccurate evaluations (Copper et al. 2018). For example, many investigators have reported similar histological findings in fish organs exposed to environmental pollutants or in fish exposed to waterborne diseases (Miki et al. 2018). In this sense, it can be more useful to use appropriate fixation and staining techniques to facilitate differential diagnosis. For this reason, it is necessary to idealize the staining quality by standardizing the fixation techniques with the tissue staining methods.

Histological preparation of gill tissue samples forms a fixed specimen that will slightly reduce over time and can be examined under the microscope and captured images. With this ideal in opinion, we aimed to improve and compare methods used in histological preparation of zebrafish gill tissue samples. In this study, it was observed satisfactory procedures for fixation and staining of gill tissues.

In large fishes, organ or tissues are dissected separately and immerses into the fixative. But, in small fishes such as himedaka or zebrafish, whole bodies of fish immersed directly into the fixative. It is well known that fish tissues are quickly reduced with autolysis after death, and therefore, the key to successful fixation is how rapidly they can inactivate endogenous enzymes than governs autolysis. Researchers (Speilberg et al. 1993, Doaa and Hanan 2013) have observed defective fixation of tissues such as the liver, intestine, and brain when whole bodies of fish are immersed in 10\% formalin. Therefore, they recommended the use of rapidlyt permeable fixatives, such as NBF and Davidson's solutions, for fish fixation. Beyond the zebrafish researchers, we have observed a number of findings for the purpose of experiments that will extend to common model system researchers. Thus, as a result of the use of Bouin's, NBF, Carnoy's, Davidson's and Dietrich's fixatives, gill tissue morphology and histological staining findings were evaluated comparatively. All fixatives used in this study provided successful fixation, but showed different effects on histomorphological structure and H\&E and MT staining reactions.

It has been reported that gill filaments and gill lamellae with well-preserved structures were observed in fish fixed with only $20 \%$ formalin solution. On the other hand, it was observed that detached of the epithelium from the capillary, and artifactual spaces formed in the gill lamellae in fish fixed with the
Bouin's or Davidson's solution only for $6 \mathrm{~h}$. Also, it was noticed that the gill structure poorly separated and the gill filaments and lamellae were not seen so clearly in the tissue samples which were fixed only with Davidson's solution. It has been determined in the fish tissues fixed with Bouin's solution for $5 \mathrm{~h}$ after $20 \%$ formalin solution fixation for $1 \mathrm{~h}$ at $4^{\circ} \mathrm{C}$, gill filaments and gill lamellae with almost wellpreserved structures. Also, epithelium lifting has been prevented in fish fixed with Davidson's solution for 5 $\mathrm{h}$ after $20 \%$ formalin solution fixation for $1 \mathrm{~h}$ at $4{ }^{\circ} \mathrm{C}$, the gill filaments and lamellae was poorly separated (Miki et al. 2018).

It has been reported that various fixatives such as Bouin's, NBF, Carnoy's, Dietrich', Davidson's, Zenker and Alcohol derivatives are used in the fixation of some tissues of zebrafish and it was determined that different fixation applications resulted in different staining results in histological examinations (Bird et al. 2012, Fournie et al. 2000, Peterson et al. 2013, Grunow et al. 2015, Copper et al. 2018). Fixatives containing acetic acids such as Bouin's, Carnoy's, Davidson's, and Dietrich's have been reported to cause erythrocyte lysis but NBF inhibits the lysis of erythrocytes. Fixatives other than NBF have been reported to cause denaturation and clotting of proteins and nucleic acids in tissues due to dehydration and hydrogen bonding due to acetic acid and alcohol (chloroform in Carnoy's) (Peterson et al. 2013). It was reported that Davidson's solution penetrates rapidly and effectively, while Dietrich's solution leads to less shrinkage and deterioration (Dietrich and Krieger 2009, Peterson et al. 2013). In our study, except for NBF, there was lysis in erythrocytes in all of the fixatives used, and furthermore, this supported the well-preserved morphology in Bouin's solution and NBF-fixed gills.

In a research, some problems have been identified in the preparation of histological samples of zebrafish tissues. The first is the differential tissue shrinkage that follows the gaps between tissues that cannot be obtained in live fish. It was proposed that shrinkage may be associated with differences between the solution and tissue osmolality and the required experiments. In addition, in some juvenile and adult fish, it was observed that the internal organs were inadequate fixed and resulted in tissue degeneration (Copper et al. 2018). In our study, depending on the used fixative types, H\&E and MT staining reaction scores showed some differences in samples in the same experimental groups. It can be said that these differences may be due to manual staining technique in histopathological examination of gill tissues. In H\&E staining, Carnoy's solution has been found to provide a more severe nuclear staining, which is thought to be due to the agglutination of nucleic acids. In addition, it was found that the most ideal $\mathrm{H} \& \mathrm{E}$ staining was with $\mathrm{NBF}$ and the other fixatives produced different intensities. Bouin's, Carnoy's and 
Davidson's solutions showed strong cytoplasmic staining with eosin. Dietrich's solution was inadequate for $H \& E$ staining and was generally weaker than other fixatives.

Although similar good staining results were obtained in the MT staining of tissues fixed with $\mathrm{NBF}$ and Carnoy's solution (Peterson et al. 2013), in our study, the most ideal MT staining density was observed in Dietrich's solution. Carnoy's and Davidson's solutions have been shown to provide an even density in MT staining. Bouin's solution has been reported to be the ideal fixative for MT staining (Singhal et al. 2016). However, in our study, Bouin's solution did not give the ideal results for MT staining in zebrafish gill tissue.

\section{CONCLUSIONS}

As a result, fixation applications using different fixatives made various effects on H\&E and MT staining techniques in gill tissue of zebrafish. Gill tissue morphology was optimally protected by Bouin's solution and NBF solution, whereas H\&E staining showed optimal results with NBF, also MT staining showed ideal results with Dietrich's solution fixation. Bouin fixative did not allow the shrinkage of the gill tissue, minimal formalin pigment formation, and enabled cellular morphological details to be seen even in the gill with complex morphology. Eosinophilic and basophilic cellular structures were clearly stained in a differential manner and generally ideal H\&E staining was identified in NBF fixation. Furthermore, the structure of collagen fibers is well preserved and optimal staining is achieved by MT staining technique in Dietrich's solution fixation. Considering the preservation of gill tissue morphology and $\mathrm{H} \& \mathrm{E}$ and MT staining methods, other fixative solutions have several disadvantages.

\section{ACKNOWLEDGMENTS}

The author declares no conflict of interests. This study was supported by The Scientific and Technological Research Council of Turkey (TÜBİTAK, Project number: 215Z467).

Bingöl University Animal Experiments Local Ethics Board dated 26.09.2014 and numbered 2014.09.02.

\section{REFERENCES}

Ahmed, H. G., Mohammed, A. Hussein, M. A comparison study of histochemical staining of various tissues after Carnoy's and formalin fixation. Sudan Journal of Medical Sciences. 2011; 5(4).

Alturkistani, HA., Tashkandi, FM., Mohammedsaleh, ZM. Histological stains: a literature review and case study. Global journal of health science, 2016; 8(3): 72.

Bancroft, JD., Gamble, M. Theory and practice of histology techniques. In: Fixation of tissues, Ed; Layton C,
Bancroft JD, Suvarna SK, 8 th Ed., Churchill Livingstone Elsevier, 2019; pp. 40-63.

Bancroft, J. D. Layton, C. Theory and practice of histology techniques. In: Connective and other mesenchymal tissues with their stains, Ed; Layton C, Bancroft JD, 8 th Ed., Churchill Livingstone Elsevier, 2019; pp. 153-175.

Bensimon-Brito, A., Cardeira, J., Cancela, ML., Huysseune, A. Witten, PE. Distinct patterns of notochord mineralization in zebrafish coincide with the localization of Osteocalcin isoform 1 during early vertebral centra formation. BMC developmental biology. 2012; 12(28).

Bird, NC., Windner, SE. Devoto, SH. Immunocytochemistry to study myogenesis in zebrafish. Myogenesis. Springer. 2012; pp.153-169.

Berzins, IK., Smolowitz, RM., Lewbart, GA., Diagnostic Techniques and Sample Handling. Invertebr. Med. Second Ed., 2011.

Brundo, MV., Salvaggio, A. Zebrafish or Danio rerio: A New Model in Nanotoxicology Study. In: Bozkurt Y, editor. Recent Adv. Zebrafish Res., Rijeka: IntechOpen; 2018.

Carson, FL., Hladik, C. Histotechnology-A Self Instructional Text. In: Connective and muscle tissue, Ed. Carson FL. Chicago, IL: American Society of Clinical Pathologists Press. 1996; pp. 134-140.

Chandrarathna, H., Nikapitiya, C., Dananjaya, S., Wijerathne, C., Wimalasena, S., Kwun, HJ., Heo, GJ., Lee, J., De Zoysa, M. Outcome of co-infection with opportunistic and multidrug resistant Aeromonas hydrophila and A. veronii in zebrafish: Identification, characterization, pathogenicity and immune responses. Fish \& shellfish immunology. 2018; 80: 573-581.

Christoffersen, TB., Kania, PW., Von Gersdorff JL., Buchmann, K. Zebrafish Danio rerio as a model to study the immune response against infection with Ichthyophthirius multifiliis. Journal of fish diseases. 2017; 40: 847-852.

Cima, L., Riva, G., D'errico, A., Casartelli-Liviero, M., Capelli, P., Tomezzoli, A., Montin, U., Carraro, A., Scarpa, A., Ghimenton, C. Fast chromotrope aniline blue special stain is a useful tool to assess fibrosis on liver biopsy during transplantation. Transplantation proceedings, Elsevier. 2017; 667-670.

Copper, JE., Budgeon, LR., Foutz, CA., Van Rossum, DB., Vanselow, DJ., Hubley, M J., Clark, DP., Mandrell, DT., Cheng, KC. Comparative analysis of fixation and embedding techniques for optimized histological preparation of zebrafish. Comparative Biochemistry and Physiology Part C: Toxicology \& Pharmacology. 2018; 208: 38-46.

Culling, CFA. Handbook of histopathological and histochemical techniques: In: museum techniques, Ed; Culling, CFA, 3 rd Ed., Butterworth-Heinemann, 1983; pp. 529-557.

Çakici, Ö., Üçüncü, Sİ. Zebra balığında Danio rerio'da (Teleostei: Cyprinidae) oosit gelişimi. Ege Journal of Fisheries and Aquatic Sciences, 2007; 24 (1).

Dietrich, D., Krieger, HO. Histological analysis of endocrine disruptive effects in small laboratory fish, John Wiley \& Sons, Inc., Hoboken, New Jersey, USA, 2009.

Doaa, MM., Hanan, H. Histological changes in selected organs of Oreochromis niloticus exposed to doses of lead acetate. J Life Sci Biomed. 2013; 3: 256-263.

Eltoum, I., Fredenburgh, J., Myers, RB., Grizzle, WE. Introduction to the theory and practice of fixation of tissues. Journal of Histotechnology. 2001; 24: 173-190. 
Feist, SW., Lang, T., Stentiford, GD., Road, B., Nothe, T. Biological effects of contaminats: Use of liver pathology of the European flatfish dab (Limanda limanda L .) and flounder (Platichthys flesus L .) for monitoring. 2004.

Flores-Lopes, F., Thomaz, A. Histopathologic alterations observed in fish gills as a tool in environmental monitoring. Brazilian Journal of Biology. 2011; 71: 179188

Fournie, JW., Krol, RM., Hawkins, WE. Fixation of fish tissues. In: The laboratory fish. Academic Press. 2000. pp. 569-578.

Genten, F., Terwinghe, E., Danguy, A. Atlas of Fish Histology. Science Publishers, Enfield, NH, USA, 2010.

Gnanapragasam, VJ. Unlocking the molecular archive: the emerging use of formalin-fixed paraffin-embedded tissue for biomarker research in urological cancer. BJU international. 2010; 105: 274-278.

Grunow, B., Kirchhoff, T., Lange, T., Moritz, T., Harzsch, S. Histochemistry on vibratome sections of fish tissue: a comparison of fixation and embedding methods. Aquatic Biology. 2015; 23: 251-263.

Hadi, A., Alwan, S. Histopathological changes in gills, liver and kidney of fresh water fish, Tilapia zillii, exposed to aluminum. International Journal of Pharmacy \& Life Sciences. 2012; 3 (11).

Howard, DW., Lewis, EJ., Keller, BJ., Smith, CS. Histological techniques for marine bivalve mollusks and crustaceans. 2004.

Huiting, L., Laroche, F., Feng, H. The zebrafish as a tool to cancer drug discovery. Austin journal of pharmacology and therapeutics. 2015; 3: 1069.

Khan, R., Thulin, J. Influence of pollution on parasites of aquatic animals. Advances in parasitology. Academic Press. 1991. pp. 201-238.

Kumar, GL., Kiernan, JA. Dako Education Guide. In: Special Stains and H \& E | Pathology 2010. Dako North America.

Latendresse, JR., Warbrittion, AR., Jonassen, H., Creasy, DM. Fixation of testes and eyes using a modified Davidson's fluid: comparison with Bouin's fluid and conventional Davidson's fluid. Toxicologic pathology. 2002; 30: 524-533.

Mao, H., Su, P., Qiu, W., Huang, L., Yu, H., Wang, Y. The use of Masson's trichrome staining, second harmonic imaging and two-photon excited fluorescence of collagen in distinguishing intestinal tuberculosis from Crohn's disease. Colorectal Disease. 2016; 18: 1172-1178.

Maraschin, BJ., Silva, VPD., Rock, L., Sun, H., Visioli, F., Rados, PV., Rosin, MP. Optimizing Fixation Protocols to Improve Molecular Analysis from FFPE Tissues. Brazilian dental journal. 2017; 28: 82-84.

Martinello, T., Pascoli, F., Caporale, G., Perazzi, A., Iacopetti, I., Patruno, M. Might the Masson trichrome stain be considered a useful method for categorizing experimental tendon lesions? Histol Histopathol. 2015; 30: 963-969

Matthews, M., Varga, ZM. Anesthesia and euthanasia in zebrafish. ILAR journal. 2012; 53: 192-204.

Miki, M., Ohishi, N., Nakamura, E., Furumi, A., Mizuhashi, F. Improved fixation of the whole bodies of fish by a double-fixation method with formalin solution and Bouin's fluid or Davidson's fluid. Journal of Toxicologic Pathology. 2018; 31(3): 201-206.
Mohseny, A., Hogendoorn, P. Zebrafish as a model for human osteosarcoma. Current Advances in Osteosarcoma. Springer, Cham. 2014; pp. 221-236.

Morris, JA. Zebrafish: a model system to examine the neurodevelopmental basis of schizophrenia. Progress in brain research. Elsevier. 2009; 179: 97-106.

Mueller, C., Harpole, MG., Espina, V. One-step preservation and decalcification of bony tissue for molecular profiling. Molecular Profiling. Springer. 2017; 85-102.

Muto, A., Kawakami, K. Prey capture in zebrafish larvae serves as a model to study cognitive functions. Frontiers in neural circuits. 2013; 7: 110 .

Nechifor-Boilă, AC., Loghin, A., Vacariu, V., Halațiu, VB., Borda, A. The storage period of the formalin-fixed paraffin-embedded tumor blocks does not influence the concentration and purity of the isolated DNA in a series of 83 renal and thyroid carcinomas. Rom J Morphol Embryol. 2015; 56: 759-763.

Newman, M., Ebrahimie, E., Lardelli, M. Using the zebrafish model for Alzheimer's disease research. Frontiers in genetics. 2014.; 5: 189.

Nusslein-Volhard, C. \& Dahm, R. Zebrafish, Ed; Ralf. Oxford University Press. 2002.

Pereira, MA., Dias, AR., Faraj, SF., Cirqueira, CDS., Tomitao, MT., Carlos NS., Ribeiro JRU. \& De Mello, ES. Carnoy's solution is an adequate tissue fixative for routine surgical pathology, preserving cell morphology and molecular integrity. Histopathology. 2015; 66: 388-397.

Peterson, TS., Kent, ML., Ferguson, JA., Watral, VG., Whipps, CM. Comparison of Fixatives, Fixation Time, and Severity of Infection on PCR Amplification and Detection of Mycobacterium marinum and Mycobacterium chelonae DNA in Paraffin-Embedded Zebrafish (Danio rerio). Diseases of aquatic organisms. 2013; 104: 113.

Pikarsky, E., Ronen, A., Abramowitz, J., Levavi-Sivan, B., Hutoran, M., Shapira, Y., Steinitz, M., Perelberg, A., Soffer, D., Kotler, M. Pathogenesis of acute viral disease induced in fish by carp interstitial nephritis and gill necrosis virus. Journal of virology. 2004; 78: 9544-9551.

Progatzky, F., Cook, HT., Lamb, JR., Bugeon, L., Dallman, MJ. Mucosal inflammation at the respiratory interface: a zebrafish model. American Journal of Physiology-Lung Cellular and Molecular Physiology. 2016; 310: 551-561.

Rahunen, K., Rieppo, L., Lehenkari, P., Finnilä, M. \& Saarakkala, S. Evaluation of quantitativity of histological collagen stains in articular cartilage. Osteoarthritis and Cartilage. 2016; 24: 307-308.

Roberts, RJ. Fish pathology. In: Laboratory Methods, Ed; Roberts RJ, Smail DA, Munro ES, 4th Ed., John Wiley \& Sons. 2012; pp. 439-480.

Sahota, PS., Popp, JA., Hardisty, JF., Gopinath, C. Toxicologic pathology: nonclinical safety assessment. $1_{\text {st }}$ Ed., CRC press. 2013.

Singhal, P., Singh, NN., Sreedhar, G., Banerjee, S., Batra, M., Garg, A. Evaluation of histomorphometric changes in tissue architecture in relation to alteration in fixation protocol-an invitro study. Journal of clinical and diagnostic research: JCDR. 2016; 10: ZC28.

Souza, JP., Baretta, JF., Santos, F., Paino, IM. \& Zucolotto, V. Toxicological effects of graphene oxide on adult zebrafish (Danio rerio). Aquatic toxicology. 2017; 186: $11-18$. 
Spaniol, K., Guthoff, R., Schrader, S., Borrelli, M.,, Kajasi, N., Schramm, M., et al. Diagnostik von Binde- und Hornhauterkrankungen. Klin Monbl Augenheilkd 2016;233:e17-28.

Speilberg, L., Evensen, Ø., Bratberg, B., Skjerve, E. Evaluation of five different immersion fixatives for light microscopic studies of liver tissue in Atlantic salmon Salmo salar. Diseases of aquatic organisms. 1993; 17: 4755 .

Stefanović, D., Samardžija, G., Redžek, A., Arnaut, M., Nikin, Z., Stefanović, M. Buffered RomanowskyGiemsa method for formalin fixed, paraffin embedded sections: taming a traditional stain. Biotechnic \& Histochemistry. 2017; 92: 299-308.

Strzyzewska, E., Szarek, J., Babinska, I. Morphologic evaluation of the gills as a tool in the diagnostics of pathological conditions in fish and pollution in the aquatic environment: a review. Veterinární Medicína. 2016; 61(3).

Telser, A. Histological and histochemical methods: theory and practice, 3rd edition. Shock 2006.

Ung, CY., Lam, SH., Hlaing, MM., Winata, CL., Korzh, S., Mathavan, S., Gong, Z. Mercury-induced hepatotoxicity in zebrafish: in vivo mechanistic insights from transcriptome analysis, phenotype anchoring and targeted gene expression validation. Bmc Genomics. 2010; 11: 212.

Uslu, B., Dioguardi, CC., Haynes, M., Miao, DQ., Kurus, M., Hoffman, G., Johnson, J. Quantifying growing versus non-growing ovarian follicles in the mouse. Journal of ovarian research. 2017; 10: (3).

Westerfield, $\mathbf{M}$. The zebrafish book: a guide for the laboratory use of zebrafish. 2000; http://zfin.org/zf_info/zfbook/zfbk.html; Accessien date: 02.02.2019.

Wilson, JM., Bunte, RM., Carty, AJ. Evaluation of rapid cooling and tricaine methanesulfonate (MS222) as methods of euthanasia in zebrafish (Danio rerio). Journal of the American Association for Laboratory Animal Science. 2009; 48: 785-789. 